\title{
Administrative Officers
}

Aside from the Governor and Lieutenant Governor there are other elective officials who perform important functions - the Secretary of State, Auditor of State, Treasurer of State, Attorney General, Superintendent of Public Instruction, and Secretary of Agriculture.

The Secretary of State is an elective officer with many important duties to perform. The work of his office is divided into three principal departments - the land office, the division of corporations and trademarks, and the general or custodial office. The state land office maintains the records of the acquisition, annexation, or disposal of land by the state and by incorporated cities and towns. If an individual acquires land from the state, the deed or patent is signed by the Governor and attested with the state seal.

Charters for all Iowa corporations and cooperative associations are issued by the Secretary of State. Foreign corporations doing business in Iowa are required to obtain permits from that officer. Protective registrations of trademarks, labels, and forms of advertising are also obtained there.

The Secretary of State's office is the storehouse of the state's official documents. The original con- 
stitution of 1857 is on display in his office. When a law is passed and signed by the Governor, the original document is filed with the Secretary of State. Thus one may find in his office the original measure that was passed in 1847 for the founding of the State University of Iowa. In the passage of such a law the enrolled bill constitutes the legal proof of what the legislative action was in a particular case. This becomes a matter of much interest, and is important documentary evidence if there should be an error in transmitting or printing the law at a later date.

When a legislative act goes into effect by publication, the Secretary of State endorses on the enrolled bill a certificate giving the names and dates of the papers in which it was published. Copies of laws of a general nature which take effect upon publication are sent to the clerk of the district court in each county where they are kept for six months or until the laws are officially published.

All petitions for nomination papers, and all state election returns are filed in the Secretary of State's office. These political statistics provide an indispensable source of information about the voting habits of Iowans.

Many official duties and activities converge in the Secretary of State's office. Historically, it is interesting to note that the Iowa Highway Patrol 
System originated and developed under the supervision of the Secretary of State. It was later transferred to the Department of Public Safety.

The Secretary of State is chairman of the Iowa Real Estate Commission, a member of the State Executive Council, the Board of Health, the Printing Board, and the Employment Agency Commis sion.

The Auditor of State performs the intricate and comprehensive accounting and auditing work of the state. At frequent intervals he makes full settlement between the state and all state officers and departments and all persons receiving or expending state funds, and makes a complete audit of the books, records, and accounts of every executive department of the state. The municipal finance department, the county accounting department, and the fiscal affairs of all political subdivisions are under the management of the State Auditor. All offices of the 99 counties of the state are examined annually. City, township, and school funds may also be audited upon request.

The Auditor submits annual and biennial finan cial reports, as well as an individual audit report to the Governor. He also serves as a member of the Executive Council, the Printing Board, the Geological Board, the Bonus Board, and the Board of Health.

The Treasurer of State is a constitutional offi- 
cer elected at the regular state biennial election. All state revenues are received and disbursed by the treasury department under the direct supervision of the Treasurer. A record is maintained to show the sources of all income, the funds to which such incomes apply, the dates received, and the amounts received. Disbursements are made only upon warrants issued as certified by the State Comptroller. A record is kept of each warrant paid, as well as the date of issuance, date of payment, to whom paid, and against which fund such warrant is drawn.

The Treasurer, with the consent of the Executive Council, may designate banks in Iowa which shall serve as depositories of state funds, and indicate the maximum amount of money that may be deposited in any such bank. Accounts, funds, and records in the treasury department are carefully safeguarded. All accounts are audited daily by the Auditor of State, and examined quarterly under the direction of the Governor.

The Attorney General of the state is elected biennially. He is the attorney and legal adviser for the various state departments. It is his duty to prosecute for or defend the state in all actions and proceedings, civil and criminal, in which the state is a party or is interested, when requested to do so by the Governor, Executive Council, or General Assembly. He may also appear on his own mo 
tion. He must prosecute or defend for the state in all cases in the Supreme Court in which the state is a party or interested. He is given supervisory power over county attorneys and in a gen eral way is responsible for law enforcement throughout the state.

The Attorney General frequently assists the General Assembly in the drafting of important bills. Thus, in 1949, the Attorney General was called upon to draft a soldiers' bonus bill that could be presented to the Fifty-third General As sembly with little delay, and one that would with stand the tests in the courts in litigation that was sure to follow. By virtue of his office, the Attorney General is chairman of the Board of Law Examiners, and is a member of the Printing Board.

The office of Superintendent of Public Instruction was established by the General Assembly in 1864. The Superintendent, elected by the people for a term of four years, has general supervision and control over the public schools of the state, including rural, graded, high schools, and public junior colleges. Courses of study are prepared by this department. The certification of teachers, the inspection of schools, and the distribution of state aid to schools are all functions of this office. Indeed, this department of government is closely affiliated with educational interests throughout the state. The Superintendent of Public Instruction 
is President and Executive Officer ex officio of the State Board of Educational Examiners and of the State Board of Vocational Education.

The Fortieth General Assembly, in 1923, abolished a number of existing boards and commissions, and consolidated their work under a newlyorganized Iowa Department of Agriculture "for the express purpose of promoting and advancing the interests of agriculture." This department, originally established in 1900, was now to be headed by an elected Secretary of Agriculture. Various divisions, such as the dairy and food division, animal husbandry, agricultural statistics, entomology, and the weather division are included in this department. These divisions are under the general supervision of the Secretary of Agriculture, who is also a member of the Executive Council.

In addition to the state elective officials there are many appointive officers, boards, and commis sions actively engaged in state administrative work. In this group are the Comptroller, Adjutant General, Board of Control, Board of Education, Board of Parole, Board of Social Welfare, State Fair Board, Printing Board, Department of Public Safety, Banking Department, Bureau of Labor, Tax Commission, Highway Commission, Com missioner of Insurance, Industrial Commission, Conservation Commission, Liquor Control Commission, Employment Security Commission, Mine 
Inspectors, Fire Marshal, and a variety of other important officials.

One of the divisions of state government which affords excellent opportunities for the study of history and government is the Department of History and Archives at Des Moines. There one may find a large library of history and genealogy, a famous collection of autographs and photographs, many valuable historical relics, a vast natural history museum, a gallery of portraits of distinguished Iowans, and the public archives consisting of millions of documents and records - a veritable storehouse of Iowa history.

By studying the various departments and divisions of our government, by knowing their functions, their duties, and their powers, we may become better qualified to participate in governmental activities, and thereby become better citizens. 